\title{
Is gender a risk factor for cataract?
}

\section{Saman Wimalasundera}

Professor and Head, Department of Community Medicine, Faculty of Medicine, University of Ruhuna, Karapitiya, Galle.

\section{Introduction}

Age related cataract is the major cause of low vision and blindness in the world today ${ }^{1}$ with 17 million bilaterally blind in $1990^{2}$.

Commonly recognized clinical sub-types of cataract are nuclear, cortical and posterior subcapsular types (PSC). However, it is not very clear how these clinical sub-types correspond to distinct etiological entities. The current theories developed on cataract formation do not distinguish between the clinical sub-types ${ }^{2}$. Surprisingly, many biochemical changes in the lens that cause cataract are also found in aging lenses with normal clarity ${ }^{3}$.

Reactive oxidizing chemicals such as superoxide, hydrogen peroxide and hydroxyl radicals are toxic to biomolecules and are capable of producing cataract due to oxidative stress. The human lens possesses various defences against such oxidative damage that include small molecular anti-oxidants such as glutathione, vitamin $\mathrm{C}$, vitamin $\mathrm{E}$ and enzymes such as catalase, glutathione peroxidase and superoxide dismutase. Repair systems of the lens remove damaged proteins ${ }^{4}$. All these systems become deteriorated under extreme oxidative stress or during aging process. Aging will ultimately result in certain biochemical changes in the lens that includes disulfide cross-Linkages which lead to insoluble high molecular weight aggregates ${ }^{5}$ and peroxidation of membrane lipids. The oxidative damage to the lens epithelial cell DNA causes apoptosis ${ }^{6}$. In animal models the morphological appearance of oxidative cataract resembles both cortical and nuclear types ${ }^{7}$. Pathology of PSC cataract is quite different. It may be due to posterior migration of lens epithelial cells. An unknown factor is operating here to disrupt the cell to cell contact. Another mechanism put forward for cataract or genesis is the polyol pathway. Excess glucose are converted in the lens by aldose reductase to sorbitol. Sorbitol accumulations in the lens causes increased osmotic pressure causing cell damage that lead to opacification but clinical studies have shown a failure for aldose reductase inhibitors to prevent cataract in human lens ${ }^{8}$. It is also hypothesized that direct damage by ultraviolet $\mathrm{A}$ and $\mathrm{B}$ radiation may result in cataract ${ }^{8}$.

Data collection on prevalence of cataract blindness is always subjected to misclassification bias ${ }^{9}$ because a dense obvious 
age released cataract may not reveal a possibility of having glaucoma or macular damage or any other posterior segment pathology unless specific investigations are performed. Reported rates for the three most common sub-types of cataract have shown a great variability in age race and gender distribution in many studies performed in the west ${ }^{10}$. One way of finding the impact of cataract on the healthcare system is to measure the prevalence of surgical cataract extraction. This finding is dependent and influenced by the availability of surgical services and demand in a district or a country. But it provides an important and useful estimate of potential cataract burden in a population and different distributions ${ }^{11}$.

\section{Objective}

To find the impact of cataract on healthcare system by measuring the prevalence of surgical cataract extractions and its gender distribution as a risk factor.

\section{Methodology}

As mentioned in the introduction, the number of cataracts performed was used as a gauging system to find the impact of cataract on healthcare system in this study. Prevalence values and distribution of age and gender were analysed using available information. In Galle district the prime institution that performs cataract surgery is Karapitiya Teaching Hospital. Small number of cataract surgeries is being done at the private sector. Co-operative Hospital is one of the major institutions where cataract surgeries are being done at the private sector. Cataract surgeries performed over past 5 years period (2001-2006) in these two institutions were analyzed using data available from operation registers. Adjoining districts in Southern Province, i.e. Matara and Hambantota Hospitals were having functioning eye units with Eye Surgeons for this whole period. Patients who were admitted to Teaching Hospital Karapitiya from these areas for cataract surgeries were excluded from the study. For prevalence calculations data from census of population 2001 was used for males and females of Galle district in their relevant age categories. Data analysis was performed to find the prevalence values according to gender and age.

\section{Findings}

More than sixteen thousand entries on cataract surgeries over 5 year period starting from 2001 were analysed.

Table 1 - Cataract surgeries performed at Teaching Hospital, Karapitiya and Co-operative Hospital, Galle for the period of 2001 - 2006.

\begin{tabular}{lcccc}
\hline & Male & Female & Total & \\
\hline $\begin{array}{l}\text { Teaching Hospital, } \\
\text { Karapitiya }\end{array}$ & 5976 & 8504 & 14,480 & $90.4 \%$ \\
$\begin{array}{l}\text { Co-operative Hospital, } \\
\text { Galle }\end{array}$ & 605 & 936 & 1541 & $9.6 \%$ \\
\hline Total & $\mathbf{6 5 8 1}$ & $\mathbf{9 4 4 0}$ & $\mathbf{1 6 0 2 1}$ & \\
\hline
\end{tabular}

$90 \%$ of cataract surgeries of Galle District had been performed at the public sector institution. 
Table 2 - Age and gender distribution of Cataract surgeries

\begin{tabular}{|c|c|c|c|c|c|c|c|c|c|}
\hline \multirow{3}{*}{ Age } & \multicolumn{9}{|c|}{ Surgeries at Both Places } \\
\hline & \multicolumn{4}{|c|}{ Male } & \multicolumn{5}{|c|}{ Female } \\
\hline & THK & Co-op & Total & $\%$ & THK & Co-op & Total & $\%$ & Grand Total \\
\hline$>30$ & 138 & 09 & 147 & 2.23 & 109 & 12 & 121 & 1.28 & 268 \\
\hline $30-39$ & 92 & 05 & 97 & 1.47 & 113 & 09 & 122 & 1.29 & 219 \\
\hline $40-49$ & 380 & 33 & 413 & 6.27 & 585 & 55 & 640 & 6.77 & 1053 \\
\hline $50-59$ & 1213 & 127 & 1340 & 20.36 & 1737 & 189 & 1926 & 20.40 & 3266 \\
\hline $60-69$ & 1958 & 195 & 2153 & 32.71 & 3199 & 363 & 3562 & 37.73 & 5715 \\
\hline Above 70 & 2195 & 236 & 2431 & 36.93 & 2761 & 308 & 3069 & 32.51 & 5500 \\
\hline Total & 5976 & 605 & 6581 & 100 & 8504 & 936 & 9440 & 100 & 16021 \\
\hline
\end{tabular}

A steady increase of cataract surgeries after the $3^{\text {rd }}$ decade of life is shown both in males and females. The age group of 30-39 years showed the least prevalence and a sudden increase was seen after 50 years.

Table 3 - Prevalence* of any cataract** by age and gender

\begin{tabular}{|c|c|c|c|c|c|}
\hline Age & $\begin{array}{l}\text { Population } \\
\text { Male }\end{array}$ & $\begin{array}{l}\text { Population } \\
\text { Female }\end{array}$ & $\begin{array}{l}\text { Prevalence } \\
\quad \text { Male }\end{array}$ & $\begin{array}{c}\text { Prevalence } \\
\text { Female }\end{array}$ & $\begin{array}{c}\text { Total Cataract } \\
\text { Prevalence }\end{array}$ \\
\hline$>30$ & 261,391 & 257,525 & 0.112 & 0.094 & 0.103 \\
\hline $30-39$ & 65,509 & 72,863 & 0.297 & 0.334 & 0.317 \\
\hline $40-49$ & 58,385 & 63,559 & 1.414 & 2.014 & 1.727 \\
\hline $50-59$ & 44,709 & 51,049 & 5.994 & 7.546 & 6.821 \\
\hline $60-69$ & 28,700 & 34,507 & 15.003 & 20.645 & 18.082 \\
\hline \multirow[t]{2}{*}{$<70$} & 24,155 & 29,135 & 20.128 & 21.068 & 20.642 \\
\hline & 482,849 & 508,638 & 2.726 & 3.712 & 3.232 \\
\hline
\end{tabular}

\section{Discussion and Conclusion}

The total prevalence for cataract surgeries among males and females is $3.2 / 1000$ population and for males and females separately it was 2.7 and 3.7 / 1000 population showing a female preponderance.

The cataract surgery prevalence shown in table 3 almost exclusively relate to the District of Galle. The proportion of the population who have undergone cataract surgery has a marked increase in the decades after $40 \mathrm{yrs}$. Sudden increase of cataract surgical prevalence after 50 years is suggestive of the occurrence of cataract after 50 years is higher. Prevalence of cataract surgery is significantly lower in young age groups. Female gender has shown an increased age adjusted rate of cataract surgical prevalence in this study.
Statistical calculation using goodness of fit test shows a significant increase of cataract surgical prevalence among females than males $(\mathrm{P}=0.05)$. Relative risk calculated using the cataract surgeries performed as incidence cases shows a relative risk of 1.36 among females compared to males in getting cataract. This is a significantly higher risk among females. $(\mathrm{CI}=1.32-1.40)$. All age groups have shown a higher prevalence of surgical cataract in females, except for the age group of less than 30 years. The highest male female difference was shown in the age group of 60-69 years. The total prevalence of surgical cataract of $0.32 \%$ is comparatively a smaller value compared to the expected National prevalence of cataract values published by Eye Foundation in 
Sri Lanka i.e. $0.7 \%$. This finding may suggest poor health-seeking behaviour among people with cataract and as a result there may be a backlog of cataract remaining in Galle District yet.

It has been shown in Australian Blue Mountain Study ${ }^{12,13}$ that females gender is generally associated with increased age adjusted risk of cataract and the findings of our study are also similar to the Australian Study. These findings are suggestive of gender as a risk factor for cataract and further studies to confirm this finding will be necessary.

\section{Acknowledgement}

I appreciate the support given by Dr. Tharaka Kusaladharma, Consultant Eye Surgeon, Teaching Hospital, Karapitiya for providing all necessary support for this study and Dr. Upul Priyadarshana of Department of Community Medicine for helping in the study.

\section{References}

1. Thylefors B, Negrel AD, Pararajasekaram R, Dadzie KY. Global data on blindness, Bull. World Health Org, 1995; 73: $115-21$.

2. Foster A, Johnson G, Magnitude and causes of blindness in the developing World, Int. Ophthalmol 1990; 14: 13540 .

3. Nathan GC, Hagh RT, Agre related cataract. Epidemiology of Eye Diseases 2003; 105-15.

4. Hnang LL, Shang F, Nowel TR Jr. Taylor A. Degradation of differentially oxidized alpha crystalline in bovine lens epithelial cells Exp. Eye Res 1995; 61: 45-54.
5. Lou MF, Dickerson JE Jr., Garadi R, Role of protein thiol mixed disulfides in cataract genesis, Exp Eye Res. 1990; 50(6): 819-26.

6. Li WC, Kusak JR, Dunn K, et al lens epithelial cell apoptosis appears to be a common cellular basis for non congenital cataract development. Humans and animals $J$ Cel Biology 1995; 130: 169-81.

7. Andley UP, Liang JJ. Low MF, Biochemical Mechanisms of age related cataract. In: Jacobiak P (ed) Principles and Practice of Ophthalmology $2^{\text {nd }} e d$, WB Saunders Co., New York, 1999; 1433.

8. Harding JJ. Can cataract be prevented? Eye 1999; 13: 451-6.

9. Dandona L, Dandona R, Naduvilath JJ. et al. Is current eye care policy focus almost exclusively on cataract adequate to deal with blindness in India? Lancet 1998; 351: 1312-6.

10. West SK, Munoz B, Schein OD, Duncun DD, Rubin GS. Racial differences in Lens opacities the Salisburg eye evaluation (SEE) project. Am. J. Ophthalmol. 1998; 148: 1033-9.

11. Congton N, West SK, Buhrman RR, Kouzis A, Munoz B. Prevalence of the different types of Age related cataract in African Population. Invest Ophthalmol Vis Sci 2001; 42: 2478-982.

12. Cumming RG, Michel P. Hormone replacement therapy, reproductive factors and cataract. The Blue Mountain Eye Study. American Journal of Epidemiology, 1997; 145: $242-9$.

13. Michel P, Cumming RG, Attebo K, Panchapakesan J. Prevalence of cataract in Australia. The Blue Mountain Eye Study, Opthalmology, 1997; 104: 581-8. 